Article

\title{
Removal of $\mathrm{F}^{-}$from Water Using Templated Mesoporous Carbon Modified with Hydrated Zirconium Oxide
}

\author{
Tomoya Takada \\ Department of Applied Chemistry and Bioscience, Chitose Institute of Science and Technology, Bibi, \\ Chitose 066-8655, Japan; t-takada@photon.chitose.ac.jp; Fax: +81-123-27-6056
}

Received: 30 January 2020; Accepted: 6 March 2020; Published: 9 March 2020

\begin{abstract}
Three types of $\mathrm{MgO}$-templated mesoporous carbon possessing different specific surface area and pore size distribution were modified with hydrated zirconium oxide $\left(\mathrm{ZrO}_{2} \cdot \mathrm{xH}_{2} \mathrm{O}\right)$ to prepare fluoride anion $\left(\mathrm{F}^{-}\right)$adsorbents. $\mathrm{ZrO}_{2} \cdot \mathrm{xH}_{2} \mathrm{O}$ was synthesized through the auto-hydrolysis of zirconium oxychloride $\left(\mathrm{ZrOCl}_{2}\right)$ in water under the coexistence of mesoporous carbon. X-ray diffractometry (XRD) and X-ray photoelectron spectroscopy (XPS) indicated that the mesoporous carbon surfaces were coated with mainly amorphous $\mathrm{ZrO}_{2} \cdot \mathrm{xH}_{2} \mathrm{O}$. Capabilities of aqueous $\mathrm{F}^{-}$removal of the prepared adsorbents and the unmodified mesoporous carbons were compared. The $\mathrm{F}^{-}$uptake by the prepared adsorbents was larger than that observed using unmodified carbons, indicating that the $\mathrm{F}^{-}$adsorption capacity was improved through the $\mathrm{ZrO}_{2} \cdot \mathrm{xH}_{2} \mathrm{O}$ coating. Moreover, the adsorption capability was found to depend on the pore size of the mesoporous carbons. The $\mathrm{F}^{-}$uptake decreased as $\mathrm{pH}$ of $\mathrm{F}^{-}$ solution increased. Protonation and deprotonation of $\mathrm{ZrO}_{2}$ were found to affect the $\mathrm{F}^{-}$adsorption.
\end{abstract}

Keywords: mesoporous carbon; hydrated zirconium oxide; fluoride; adsorption; pore size; $\mathrm{pH}$

\section{Introduction}

Fluoride anion $\left(\mathrm{F}^{-}\right)$exists in natural water, but an overdose of $\mathrm{F}^{-}$has been known to cause serious diseases, such as skeletal and dental fluorosis [1]. For example, excess intake of $\mathrm{F}^{-}$from drinking water or toothpaste results in mottled enamel. Although the $\mathrm{F}^{-}$concentration of $1-1.5 \mathrm{mg} \cdot \mathrm{L}^{-1}$ is recommended by the World Health Organization (WHO) as a standard for drinking water, water with higher $\mathrm{F}^{-}$concentrations has been used as drinking water worldwide. For example, the use of drinking water with a high $\mathrm{F}^{-}$concentration is problematic in India and in some states in Mexico [2]. Furthermore, $\mathrm{F}^{-}$is found in groundwater in the United States as well as African and Asian countries [1]. On the other hand, fluorine has important industrial applications in many fields, such as organic materials and medicine. Therefore, it is vital to remove $\mathrm{F}^{-}$from water and find ways to reutilize it.

Various adsorbents for aqueous $\mathrm{F}^{-}$adsorption have been developed and evaluated. Although one common technique for $\mathrm{F}^{-}$removal is precipitation as $\mathrm{CaF}_{2}$ by adding $\mathrm{Ca}^{2+}$ ions, this method is limited by the attainable $\mathrm{F}^{-}$concentration, and therefore it cannot be applied for advanced $\mathrm{F}^{-}$ treatment. Other well-known techniques are reverse osmosis and electrodialysis, but they are costly to use for water purification in developing countries. As one of the essential categories of $\mathrm{F}^{-}$adsorbent, inorganic substances containing metal ions and related materials have been extensively investigated, namely, iron oxide and related compounds [3-5], iron-loaded zeolite and fiber [6,7], hydroxyapatite [8], and zirconium-containing compounds and materials [9-14]. Hydrated zirconium oxide $\left(\mathrm{ZrO}_{2} \cdot \mathrm{xH}_{2} \mathrm{O}\right)$ effectively adsorbs aqueous $\mathrm{F}^{-} . \mathrm{ZrO}_{2} \cdot \mathrm{xH}_{2} \mathrm{O}$ and is easily prepared through auto-hydrolysis of zirconium oxychloride $\left(\mathrm{ZrOCl}_{2}\right)$ represented by the Equation (1) [15].

$$
\mathrm{ZrOCl}_{2}+(x+1) \mathrm{H}_{2} \mathrm{O} \rightarrow \mathrm{ZrO}_{2} \cdot x \mathrm{H}_{2} \mathrm{O}+2 \mathrm{HCl}
$$


The $\mathrm{ZrO}_{2} \cdot \mathrm{xH}_{2} \mathrm{O}$ synthesis can be carried out by simple heating of the aqueous solution of $\mathrm{ZrOCl}_{2}$. Moreover, $\mathrm{ZrO}_{2} \cdot \mathrm{xH}_{2} \mathrm{O}$ is safe and biocompatible; $\mathrm{ZrO}_{2}$ is widely used as a material of metal-free dental implants and ceramic kitchen tools, among others. Therefore, $\mathrm{ZrO}_{2} \cdot \mathrm{xH}_{2} \mathrm{O}$ is a promising candidate to perform the role of environmentally safe $\mathrm{F}^{-}$adsorbent.

Carbon materials such as activated carbon and mesoporous carbon have been widely used as deodorizers and water purifying agents because of their superior adsorption characteristics for various substances. Generally, $\mathrm{F}^{-}$adsorption capacity of unmodified carbon materials is not significant $[2,14]$. A pristine mesoporous carbon surface mainly consists of a graphitic structure containing only carbon atoms, and therefore its affinity for polar substances is not particularly exceptional. In addition, carbon surface contains oxidized moieties such as the carboxyl group (-COOH or - $\mathrm{COO}-$ ), the hydroxyl group $(-\mathrm{OH})$, and the carbonyl group $(-\mathrm{C}=\mathrm{O})$. These groups are all negatively polarized, and hence the surface functional groups and the anionic species, including $\mathrm{F}^{-}$, repel each other. Conversely, mesoporous carbons are good candidates as adsorbent supports because of their high specific surface area and chemical stability. Recently, mesoporous carbons possessing a well-defined pore size and specific surface area were successfully prepared and became commercially available. Their mesopores are introduced through impregnation of a precursor of the mesopore template with organic raw material, pyrolysis for carbonization, and finally the removal of the template [16-18]. Such mesoporous carbon is a possible candidate as a novel $\mathrm{F}^{-}$adsorbent support, as aqueous $\mathrm{F}^{-}$solution can infiltrate into the mesopore unlike microporous carbon. If an adsorbent mainly possesses micropore, an aqueous solution would be largely unable to infiltrate deeply into the pore because of its surface tension.

In contrast, the aqueous solution can infiltrate into a relatively larger mesopore. Subsequently, $\mathrm{F}^{-}$ adsorption capacity is higher when using templated mesoporous carbons than microporous carbons. By modifying the mesoporous carbon surface with other adsorbents such as $\mathrm{ZrO}_{2} \cdot \mathrm{xH}_{2} \mathrm{O}$ mentioned above, the $\mathrm{F}^{-}$adsorption capacity of mesoporous carbon can be markedly improved $[9,10]$. However, the dependence of the adsorption capacity on the pore size of mesoporous carbon supports has not been examined. Additionally, the infiltration of aqueous $\mathrm{F}^{-}$the solution is affected by the pore size.

In this work, three commercial mesoporous carbons possessing different mesopore size and specific surface area were employed to prepare $\mathrm{ZrO}_{2} \cdot \mathrm{xH}_{2} \mathrm{O} /$ carbon adsorbents and to compare their $\mathrm{F}^{-}$adsorption capacity. $\mathrm{ZrO}_{2} \cdot \mathrm{xH}_{2} \mathrm{O}$ was synthesized through auto-hydrolysis of $\mathrm{ZrOCl}_{2}$ in water under the coexistence of one of the mesoporous carbons. The $\mathrm{F}^{-}$adsorption characteristics of the prepared adsorbents and the unmodified mesoporous carbons were compared based on Freundlich adsorption isotherm. The effects of mesopore size and $\mathrm{pH}$ on $\mathrm{F}^{-}$uptake were discussed based on experimental results.

\section{Materials and Methods}

\subsection{Materials}

The materials used for the preparation of $\mathrm{F}^{-}$adsorbents were mesoporous carbons possessing MgO-templated mesopore with different pore structures (Toyo Tanso, Co. Ltd., Osaka, Japan) and zirconium oxychloride octahydrate $\left(\mathrm{ZrOCl}_{2} \cdot 8 \mathrm{H}_{2} \mathrm{O}\right.$, Junsei Chemicals, Co. Ltd., Tokyo, Japan). The product IDs, the specific surface areas, and the mesopore diameters of the mesoporous carbons are listed in Table 1. Numbers contained in the product IDs (010, 030, and 150) stipulate their mesopore diameter in $\mathrm{nm}$. These materials were used without further purification.

Sodium fluoride standard solution (NaF, $1000 \mathrm{mg} / \mathrm{L}$, TOA DKK, Co. Ltd., Tokyo, Japan) and total ionic strength adjusting buffer TISAB-01 (TOA DKK, Co. Ltd., Tokyo, Japan) were used to carry out $\mathrm{F}^{-}$adsorption experiments. To make $\mathrm{pH}$ of the sample $\mathrm{F}^{-}$solutions $5-10$, buffer solutions prepared using Good's buffer \{2-[4-(2-hydroxyethyl)-1-piperazinyl]ethanesulfonic acid (HEPES) or 2-(N-morpholino)ethanesulfonic acid (MES), Kishida Chemical, Co. Ltd., Osaka, Japan\} and sodium hydroxide standard solution $(0.1 \mathrm{~mol} / \mathrm{L}$, Junsei Chemicals, Co. Ltd., Tokyo, Japan) were used. 
Table 1. Information on the mesoporous carbons used in this study.

\begin{tabular}{ccc}
\hline Product ID & Specific Surface Area $\mathbf{~}^{\mathbf{1}} \mathbf{m}^{\mathbf{2}} \mathbf{g}^{\mathbf{- 1}}$ & Mesopore Diameter $/ \mathbf{n m}$ \\
\hline MJ(4)010 & 1100 & 10 \\
MJ(4)030 & 800 & 30 \\
MJ(4)150 & 300 & 150 \\
\hline
\end{tabular}

${ }^{1}$ The specific surface area and the mesopore diameter are the nominal values publicized by the manufacturer.

\subsection{Preparation of Mesoporous Carbons Modified with $\mathrm{ZrO}_{2} \cdot \mathrm{xH}_{2} \mathrm{O}$}

An aqueous solution of $\mathrm{ZrOCl}_{2}(0.1 \mathrm{~mol} / \mathrm{L}, 100 \mathrm{~mL})$ was prepared by dissolving $\mathrm{ZrOCl}_{2} \cdot 8 \mathrm{H}_{2} \mathrm{O}$ to distilled water. One of the mesoporous carbons $(1 \mathrm{~g})$ was added to the solution, and the mixture was refluxed for three days. The product was filtered using a membrane filter ( 5 or $0.1 \mu \mathrm{m}$ mesh), washed with a large amount of water, and dried in air at $70^{\circ} \mathrm{C}$.

\subsection{Characterization of the Prepared Adsorbents}

X-ray diffraction (XRD) patterns and X-ray photoelectron spectra (XPS) of the prepared adsorbents were recorded using RINT 2000 diffractometer (RIGAKU, Co. Ltd., Tokyo, Japan) and JEOL-JPS9200 spectrometer (JEOL, Co. Ltd., Tokyo, Japan), respectively. X-rays used for the XRD measurements and scan rate were $\mathrm{CuK}_{\alpha}$ and $2^{\circ} / \mathrm{min}$. X-ray used for the XPS measurements was $\mathrm{MgK}_{\alpha}$. Specific surface areas of the adsorbents and the unmodified mesoporous carbons were calculated based on $\mathrm{N}_{2}$ adsorption isotherms obtained using Autosorb sorption analyzer (Quantachrome Instruments, Co. Ltd., Boynton Beach, FL, USA). Adsorption was performed at $-196^{\circ} \mathrm{C}$. The specific surface areas were calculated in terms of the Brunauer-Emmett-Teller (BET) analysis [19]. Scanning electron microscopic (SEM) images of the samples were recorded using a VE-8800 electron microscope (KEYENCE, Co. Ltd., Osaka, Japan).

\section{4. $F^{-}$Adsorption Experiments}

The NaF standard solution was diluted with a buffer $(0.1 \mathrm{~mol} / \mathrm{L}$ HEPESaq. for $\mathrm{pH} 7$ and $0.1 \mathrm{~mol} / \mathrm{L}$ MESaq. for $\mathrm{pH} 5$ and 10; their $\mathrm{pH}$ was adjusted by addition of $0.1 \mathrm{~mol} / \mathrm{L} \mathrm{NaOHaq.)}$ to prepare $5-50 \mathrm{mg} / \mathrm{L} \mathrm{F}^{-}$solutions. One of the prepared adsorbents or unmodified mesoporous carbons $(0.1 \mathrm{~g})$ was then added to each solution $(50 \mathrm{~mL})$. The $\mathrm{F}^{-}$adsorption was carried out using a thermostatic shaker for $24 \mathrm{~h}$ at $25^{\circ} \mathrm{C}$. The resultant mixtures were centrifuged at $3500 \mathrm{rpm}$ for $15 \mathrm{~min}$, and $20 \mathrm{~mL}$ of their supernatants were separated. Each supernatant was mixed with $20 \mathrm{~mL}$ of water to create a sufficient volume of solution for the immersion of the electrode. For the $\mathrm{pH}$ dependence observations, TISAB-01 was used for the dilution. The $\mathrm{F}^{-}$concentration of the solutions after the adsorption was measured using an ion concentration meter (F-72, Horiba, Co. Ltd., Kyoto, Japan) equipped with an $\mathrm{F}^{-}$ selective electrode (6561-10C, Horiba, Co. Ltd., Kyoto, Japan). The equilibrium $\mathrm{F}^{-}$uptake $Q_{\mathrm{F}}$ per unit weight of adsorbent $(\mathrm{mg} / \mathrm{g})$ was calculated using Equation (2)

$$
Q_{\mathrm{F}}=\left(C_{0}-C_{\infty}\right) V / w
$$

where $C_{0}(\mathrm{mg} / \mathrm{L})$ is the initial concentration of $\mathrm{F}^{-}$solution before the adsorption, $C_{\infty}(\mathrm{mg} / \mathrm{L})$ is the $\mathrm{F}^{-}$concentration at adsorption equilibrium, $V(\mathrm{~L})$ is the solution volume, and $w(\mathrm{~g})$ is the weight of adsorbent added. The $C_{\infty}$ can be obtained by doubling the $\mathrm{F}^{-}$concentration measured for the solution after the dilution.

\section{Results and Discussion}

\subsection{Characterization of Prepared Adsorbents}

Figure 1 shows the wide-scan XPS of the prepared adsorbents. The spectra indicate that $\mathrm{Zr}$ was introduced onto mesoporous carbon. The peaks that appeared at $183 \mathrm{eV}$ corresponded to $\mathrm{Zr} 3 \mathrm{~d}$ of 
$\mathrm{ZrO}_{2} \cdot \mathrm{xH}_{2} \mathrm{O}[12,20,21]$. The two peaks that appeared at $330 \mathrm{eV}$ corresponded to $\mathrm{Zr} 3 \mathrm{p}$. The molar ratios (Zr:C) of the prepared adsorbents calculated based on peak area were 95:5 for MJ(4)010, 95:5 for MJ(4)030 and 97:3 for MJ(4)150. The Zr content measured in the case of MJ(4)150 was slightly smaller than others; the mesopore of $\mathrm{MJ}(4) 150$ may have been too loose to trap $\mathrm{ZrO}_{2} \cdot \mathrm{xH}_{2} \mathrm{O}$ fine particles firmly. Note that XPS analysis may not provide a precisely quantitative composition, especially in the case of porous materials. The gravimetric analysis results described below provide the sample compositions.

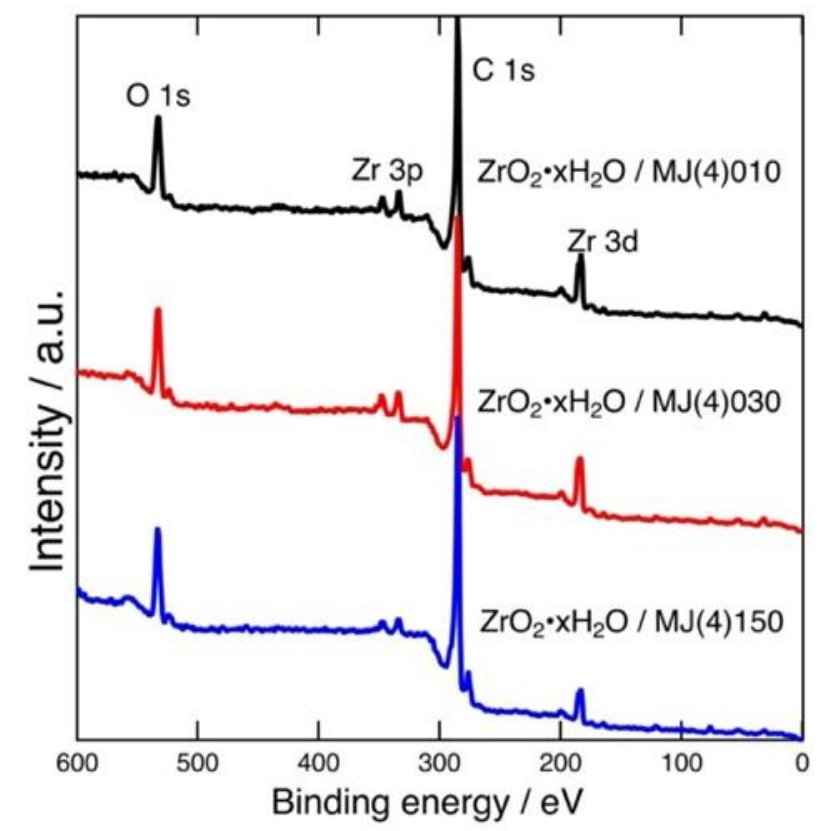

Figure 1. Wide-scan XPS of the prepared adsorbents: $\mathrm{ZrO}_{2} \cdot \mathrm{xH}_{2} \mathrm{O} / \mathrm{MJ}(4) 010$ (black), $\mathrm{ZrO}_{2} \cdot \mathrm{xH}_{2} \mathrm{O} / \mathrm{MJ}(4) 030$ (red), and $\mathrm{ZrO}_{2} \cdot \mathrm{xH}_{2} \mathrm{O} / \mathrm{MJ}(4) 150$ (blue).

The weight percent of $\mathrm{ZrO}_{2} \cdot \mathrm{xH}_{2} \mathrm{O}$ of the prepared adsorbents can be determined from the sample weights measured before and after the $\mathrm{ZrO}_{2} \cdot \mathrm{xH}_{2} \mathrm{O}$ immobilization. They were calculated as follows: $32 \%$ for $\mathrm{ZrO}_{2} \cdot \times \mathrm{H}_{2} \mathrm{O} / \mathrm{MJ}(4) 010,37 \%$ for $\mathrm{ZrO}_{2} \cdot \mathrm{xH}_{2} \mathrm{O} / \mathrm{MJ}(4) 030$, and $16 \%$ for $\mathrm{ZrO}_{2} \cdot \mathrm{xH}_{2} \mathrm{O} / \mathrm{MJ}(4) 150$. These percentages qualitatively corresponded to the $\mathrm{Zr}$ content determined by XPS. Therefore, the amount of $\mathrm{ZrO}_{2} \cdot \mathrm{xH}_{2} \mathrm{O}$ immobilized onto MJ(4)150 was found to be less than the amounts determined for the other two mesoporous carbons.

Figure 2 shows the XRD patterns of the prepared adsorbents. No peaks assigned for crystalline $\mathrm{ZrO}_{2} \cdot \times \mathrm{H}_{2} \mathrm{O}$ were found in the XRD patterns, indicating that the $\mathrm{ZrO}_{2} \cdot \mathrm{xH}_{2} \mathrm{O}$ formed was amorphous in nature. A similar result was also reported previously [12].

Specific surface areas of the prepared adsorbents are tabulated in Table 2. The surface areas decreased by the surface coverage with $\mathrm{ZrO}_{2} \cdot \mathrm{xH}_{2} \mathrm{O}$, while the order of them did not change [MJ(4)010 $>\mathrm{MJ}(4) 030>\mathrm{MJ}(4) 150]$. This result suggests that the formed $\mathrm{ZrO}_{2} \cdot \mathrm{xH}_{2} \mathrm{O}$ particle was quite fine; if the $\mathrm{ZrO}_{2} \cdot \mathrm{xH}_{2} \mathrm{O}$ particle was large-sized, the mesopore might have been blocked with the particle, and the surface area might have become distinctly smaller than that of original carbons. In addition, the surface areas reflect the mesopore size change. Although the mesopore sizes after the modification could have become smaller than those of unmodified carbons, the decrement of the surface areas was not severe, and thus the vacancy in the mesopore could be retained, even after the modification. Therefore, an effective surface area for $\mathrm{F}^{-}$adsorption was retained in addition to $\mathrm{ZrO}_{2} \cdot \mathrm{xH}_{2} \mathrm{O}$ coverage. Decrement of the specific surface area through the $\mathrm{ZrO}_{2} \times \mathrm{HH}_{2} \mathrm{O}$ coverage was apparent for $\mathrm{ZrO}_{2} \cdot \times \mathrm{H}_{2} \mathrm{O} / \mathrm{MJ}(4) 010$ and $\mathrm{ZrO}_{2} \cdot \mathrm{xH}_{2} \mathrm{O} / \mathrm{MJ}(4) 030$, while it was only a little for $\mathrm{ZrO}_{2} \cdot \mathrm{xH}_{2} \mathrm{O} / \mathrm{MJ}(4) 150$. These results support the presumption on the immobilization of $\mathrm{ZrO}_{2} \cdot \mathrm{xH}_{2} \mathrm{O}$; a relatively small amount of $\mathrm{ZrO}_{2} \cdot \mathrm{xH}_{2} \mathrm{O}$ was immobilized onto loose mesopore of $\mathrm{MJ}(4) 150$, while the marked amount of $\mathrm{ZrO}_{2} \cdot \mathrm{xH}_{2} \mathrm{O}$ was immobilized onto MJ(4)010 and MJ(4)030. 


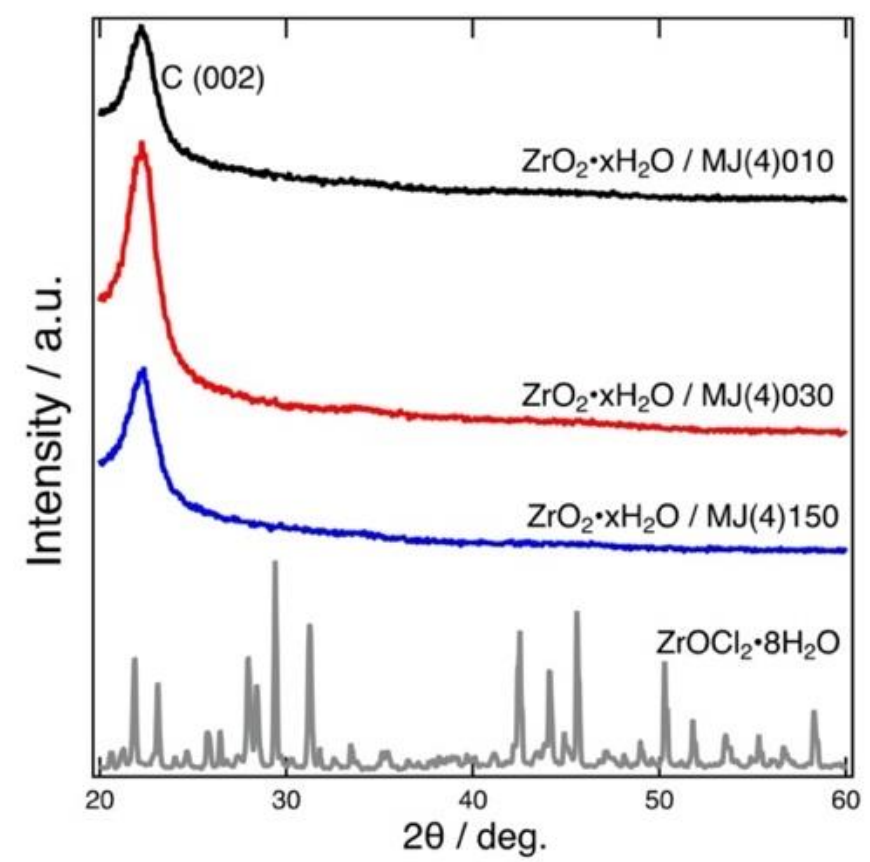

Figure 2. Powder $\mathrm{XRD}$ patterns of the prepared adsorbents: $\mathrm{ZrO}_{2} \cdot \mathrm{xH}_{2} \mathrm{O} / \mathrm{MJ}(4) 010$ (black), $\mathrm{ZrO}_{2} \cdot \mathrm{xH}_{2} \mathrm{O} / \mathrm{MJ}(4) 030$ (red), and $\mathrm{ZrO}_{2} \cdot \mathrm{xH}_{2} \mathrm{O} / \mathrm{MJ}(4) 150$ (blue). The XRD pattern of $\mathrm{ZrOCl}_{2} \cdot 8 \mathrm{H}_{2} \mathrm{O}$ (gray) is shown for comparison.

Table 2. Measured specific surface areas of the prepared adsorbents and the unmodified mesoporous carbons.

\begin{tabular}{ccc}
\hline \multirow{2}{*}{ Adsorbent } & \multicolumn{2}{c}{ Specific Surface Area/m $\mathbf{m}^{\mathbf{2}}$} \\
\cline { 2 - 3 } & Before Modification & After Modification \\
\hline $\mathrm{ZrO}_{2} \cdot \mathrm{xH}_{2} \mathrm{O} / \mathrm{MJ}(4) 010$ & 1171 & 824 \\
$\mathrm{ZrO}_{2} \cdot \mathrm{xH}_{2} \mathrm{O} / \mathrm{MJ}(4) 030$ & 807 & 602 \\
$\mathrm{ZrO}_{2} \cdot \mathrm{xH}_{2} \mathrm{O} / \mathrm{MJ}(4) 150$ & 309 & 299 \\
\hline
\end{tabular}

Figure 3 shows the SEM images of the prepared adsorbents and the unmodified carbons. These SEM images are not informative for checking whether the modification definitely occurred. Modification of the carbon particle surface with $\mathrm{ZrO}_{2} \cdot \mathrm{xH}_{2} \mathrm{O}$ was not graphically confirmed under the available magnification. These results also imply that the formed $\mathrm{ZrO}_{2} \cdot \mathrm{xH}_{2} \mathrm{O}$ was fine. This presumption is supported by the observation that, when the prepared adsorbent was filtered using a membrane filter with a $0.1 \mu \mathrm{m}$ mesh, the filtrate became cloudy, with small particles having passed through the filter. The formation of very fine particles of $\mathrm{ZrO}_{2} \cdot \mathrm{xH}_{2} \mathrm{O}$ could be visually observed.

\subsection{Freundlich Isotherms for $\mathrm{F}^{-}$Adsorption}

$\mathrm{F}^{-}$adsorption experiments were carried out to compare $\mathrm{F}^{-}$adsorption capacities of the prepared adsorbents and the unmodified mesoporous carbons. Figure 4 shows the adsorption isotherms obtained using the prepared adsorbents and the unmodified carbons. The $\mathrm{F}^{-}$adsorption capacity was improved by the $\mathrm{ZrO}_{2} \cdot \mathrm{xH}_{2} \mathrm{O}$ coverage in all cases; the amount of $\mathrm{F}^{-}$adsorbed on $\mathrm{ZrO}_{2}$-modified carbons was always larger than that adsorbed on the corresponding unmodified carbons. Notably, the increment of adsorbed $\mathrm{F}^{-}$amount observed for $\mathrm{MJ}(4) 010$ looked significant. Other adsorbents showed a similar increment, but the difference in the uptake observed before and after the $\mathrm{ZrO}_{2} \cdot \mathrm{xH}_{2} \mathrm{O}$ coverage was smaller than that observed for MJ(4)010 (Figure 4). 
(a) $\mathrm{MJ}(4) 010$

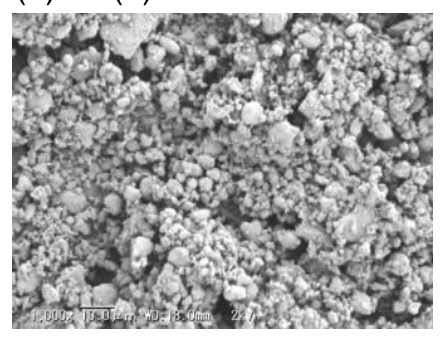

(b) $\mathrm{ZrO}_{2} \cdot \mathrm{H}_{2} \mathrm{O} / \mathrm{MJ}(4) 010$

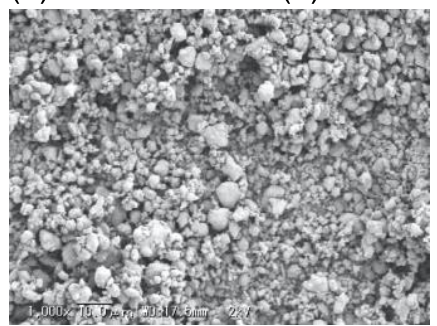

(c) $\mathrm{MJ}(4) 030$

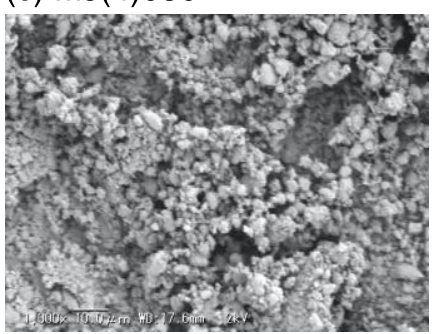

(d) $\mathrm{ZrO}_{2} \cdot \times \mathrm{H}_{2} \mathrm{O} / \mathrm{MJ}(4) 030$

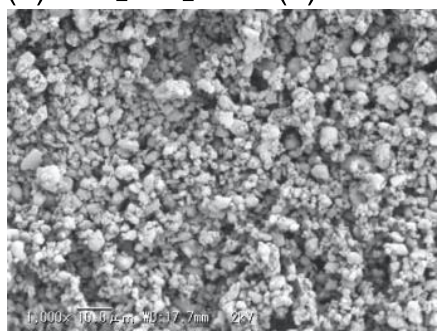

(e) $M J(4) 150$

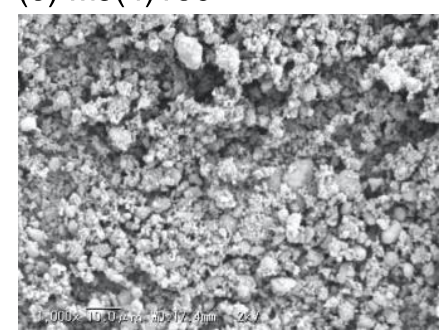

(f) $\mathrm{ZrO}_{2} \cdot \times \mathrm{H}_{2} \mathrm{O} / \mathrm{MJ}(4) 150$

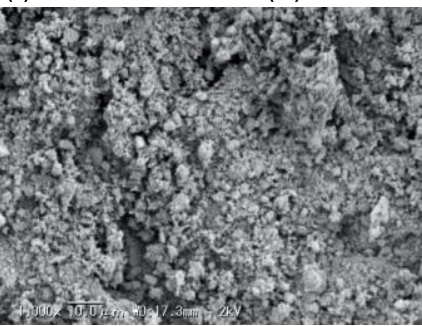

Figure 3. SEM images of the prepared adsorbents and the unmodified carbons: MJ(4)010 (a), $\mathrm{ZrO}_{2} \cdot \mathrm{xH}_{2} \mathrm{O} / \mathrm{MJ}(4) 010$ (b), $\mathrm{MJ}(4) 030$ (c), $\mathrm{ZrO}_{2} \cdot \mathrm{xH}_{2} \mathrm{O} / \mathrm{MJ}(4) 030$ (d), MJ(4)150 (e), and $\mathrm{ZrO}_{2} \cdot \mathrm{xH}_{2} \mathrm{O} / \mathrm{MJ}(4) 030$ (f).

(A)

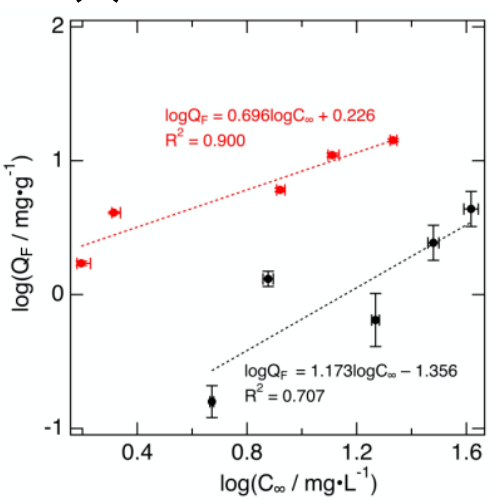

(B)

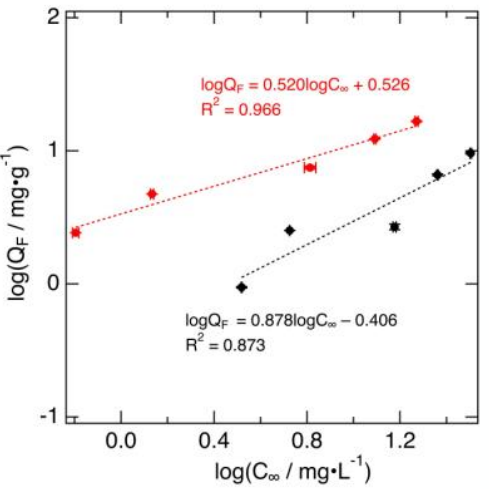

(C)

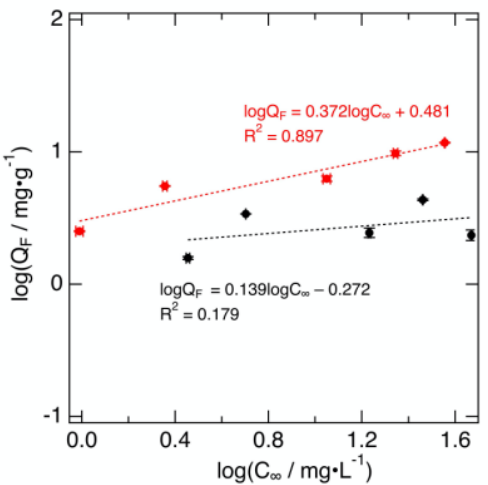

Figure 4. Adsorption isotherms of the prepared adsorbents and the mesoporous carbons: MJ(4)010 (A), MJ(4)030 (B), and MJ(4)150 (C). The red and the black markers indicate the data obtained for the $\mathrm{ZrO}_{2} \cdot \mathrm{xH}_{2} \mathrm{O} /$ mesoporous carbons and the unmodified mesoporous carbons, respectively. Equations of the Freundlich isotherm are also shown.

The adsorption data were fitted with Freundlich isotherm. The fitted functions are also shown in Figure 4. Freundlich isotherm is represented by Equation (3).

$$
Q_{\mathrm{F}}=K_{\mathrm{F}} \cdot C_{\infty}^{1 / n}
$$

where $K_{\mathrm{F}}$ (in $\mathrm{mg}^{1-1 / n} \mathrm{~g}^{-1} \mathrm{~L}^{1 / n}$ ) and $1 / n$ represents the $\mathrm{F}^{-}$adsorption capacity and intensity, respectively. Taking the logarithm of both sides, we obtain the Equation (4).

$$
\log Q_{\mathrm{F}}=\log K_{\mathrm{F}}+(1 / n) \log C_{\infty}
$$

The linear equations shown in Figure 4, obtained using unmodified mesoporous carbons, showed less linearity (their correlation coefficients were calculated to be $0.36-0.93$ ) than those obtained for the adsorbents. The unmodified carbons exhibited relatively small $Q_{\mathrm{F}}$, thus the accuracy of the measured $Q_{F}$ of unmodified carbons may have been lower than that of the prepared adsorbents. The equations obtained for the prepared adsorbents had correlation coefficients of 0.94-0.98, indicating that the 
application of the Freundlich isotherm to the data was satisfactory and reasonable. Freundlich isotherm applies to multi-layer adsorption onto the heterogeneous surface in solution, and it is known that Freundlich isotherm reasonably represents the $\mathrm{F}^{-}$adsorption behavior of $\mathrm{ZrO}_{2} \cdot \mathrm{xH}_{2} \mathrm{O}$ rather than Langmuir isotherm [12]. The $K_{\mathrm{F}}$ and the $1 / n$ were obtained from the slope and the intercept of the plot of the linearized isotherm (4), respectively. The $1 / n$ represents favorability of the application of Freundlich isotherm; the $1 / n$ between 0.1 and $1(n=1-10)$ indicates that the adsorption condition in this work was suitable. The present data were in this range $(1 / n=0.139-0.878)$ except for the case of MJ(4)010, which exhibited a larger value $(1 / n=1.173)$.

Although $K_{\mathrm{F}}$ and $n$ in Equation (4) are not theoretically derived quantities, it was reported that $K_{\mathrm{F}}$ is related to the adsorption capacity involving adsorbing space size and the adsorbate affinity [22]. Based on this consideration, $K_{\mathrm{F}}$ was employed to compare the $\mathrm{F}^{-}$adsorption capacity of the adsorbents. The values of $K_{\mathrm{F}}$ calculated based on the Freundlich isotherms are listed in Table 3.

Table 3. $\mathrm{F}^{-}$adsorption capacity $K_{\mathrm{F}}$ of prepared adsorbents and unmodified mesoporous carbons.

\begin{tabular}{cccc}
\hline \multirow{2}{*}{ Adsorbent } & \multicolumn{2}{c}{$\boldsymbol{K}_{\mathbf{F}} / \mathbf{m g}^{\mathbf{1 - 1 / n}} \mathbf{g}^{-\mathbf{1}} \mathbf{L}^{\mathbf{1 / n}}$} & \multirow{2}{*}{$\begin{array}{c}\boldsymbol{K}_{\mathbf{F}} \text { Enhancement After } \\
\text { Modification /Times }\end{array}$} \\
\cline { 2 - 3 } & Before Modification & After Modification & \\
\hline $\mathrm{ZrO}_{2} \cdot \mathrm{xH}_{2} \mathrm{O} / \mathrm{MJ}(4) 010$ & 0.044 & 1.68 & 38 \\
$\mathrm{ZrO}_{2} \cdot \mathrm{xH}_{2} \mathrm{O} / \mathrm{MJ}(4) 030$ & 0.39 & 3.35 & 8.6 \\
$\mathrm{ZrO}_{2} \cdot \mathrm{xH}_{2} \mathrm{O} / \mathrm{MJ}(4) 150$ & 0.53 & 3.03 & 5.7 \\
\hline
\end{tabular}

Judging from the calculated $K_{\mathrm{F}}$ obtained for the unmodified carbons, the order of $\mathrm{F}^{-}$adsorption capacity can be represented as $\mathrm{MJ}(4) 030 \fallingdotseq \mathrm{MJ}(4) 150>\mathrm{MJ}(4) 010$. The modification with $\mathrm{ZrO}_{2} \cdot \mathrm{xH}_{2} \mathrm{O}$ altered the adsorption capacity, and the $K_{\mathrm{F}}$ enhancements by the modification were found to be in the order of MJ(4)010 > MJ(4)030 > MJ(4)150. The $\mathrm{F}^{-}$adsorption capacity change before and after $\mathrm{ZrO}_{2} \cdot \mathrm{xH}_{2} \mathrm{O}$ modification of $\mathrm{MJ}(4) 010$ was significant.

This marked improvement of the adsorption capacity can be explained based on the change in wettability of adsorbent surface besides the affinity between $\mathrm{F}^{-}$and $\mathrm{ZrO}_{2} \cdot \mathrm{xH}_{2} \mathrm{O}$. If the mesopore size of the carbon was relatively small, $\mathrm{F}^{-}$aqueous solution could not infiltrate into the pore owing to surface tension; coverage of the pore with hydrophilic metal oxide particles could facilitate the infiltration of $\mathrm{F}^{-}$solution into the pore. In contrast, in the cases of $\mathrm{MJ}(4) 030$ and $\mathrm{MJ}(4) 150$, the $\mathrm{F}^{-}$adsorption capacity increment was moderate. The $\mathrm{F}^{-}$adsorption capacities of MJ(4)030 and MJ(4)150 were larger than that of $\mathrm{MJ}(4) 010$. Since $\mathrm{F}^{-}$could infiltrate into the mesopore of MJ(4)030 and MJ(4)150 more smoothly than $\mathrm{MJ}(4) 010$, the effect of $\mathrm{ZrO}_{2} \cdot \mathrm{xH}_{2} \mathrm{O}$ on $\mathrm{F}^{-}$adsorption capacity improvement may not have been so significant in the case of MJ(4)030 and MJ(4)150. Furthermore, with $\mathrm{ZrO}_{2} \cdot \mathrm{xH}_{2} \mathrm{O} / \mathrm{MJ}(4) 150$, the smallness of the amount of $\mathrm{ZrO}_{2} \cdot \mathrm{xH}_{2} \mathrm{O}$ immobilized would also affect its $\mathrm{F}^{-}$adsorption capacity.

Estimating $\mathrm{F}^{-}$uptake per weight of $\mathrm{ZrO}_{2} \cdot \mathrm{xH}_{2} \mathrm{O}$ of the adsorbents will be helpful for gaining an insight into the observed adsorption characteristics. The $\mathrm{F}^{-}$adsorption capacity of $\mathrm{ZrO}_{2} \cdot \mathrm{xH}_{2} \mathrm{O}$ may be altered depending on the pore structure of the unmodified carbons. For example, the particle size and the surface area of $\mathrm{ZrO}_{2} \cdot \mathrm{xH}_{2} \mathrm{O}$ formed may differ depending on the mesopore size. This estimation can be achieved by assuming that, if the weight of the adsorbents is the sum of the weight of unmodified mesoporous carbons $\left(w_{\mathrm{C}}\right)$, and the weight of $\mathrm{ZrO}_{2} \cdot \mathrm{xH}_{2} \mathrm{O}\left(w_{\mathrm{ZrO} 2} \times \mathrm{H} 2 \mathrm{O}\right)$, then the $Q_{\mathrm{F}}$ can be represented based on $Q_{\mathrm{F}}$ of unmodified carbon $\left(Q_{\mathrm{F}(\mathrm{C})}\right)$ and $Q_{\mathrm{F}}$ of $\mathrm{ZrO}_{2} \cdot \mathrm{xH}_{2} \mathrm{O}\left(Q_{\mathrm{F}(\mathrm{ZrO} 2 \times \mathrm{H} 2 \mathrm{O})}\right)$. Based on this assumption, $Q_{\mathrm{F}(\mathrm{ZrO} 2 \times \mathrm{H} 2 \mathrm{O})}$ for the adsorbents can be estimated from the experimentally-measured $Q_{\mathrm{F}}$ and $Q_{\mathrm{F}(\mathrm{C})}$. This assumption is not perfectly appropriate, because the mesoporous carbon surface is partially covered with $\mathrm{ZrO}_{2} \cdot \mathrm{xH}_{2} \mathrm{O}$, and hence the actual $Q_{\mathrm{F}(\mathrm{C})}$ expected for the adsorbents is always smaller than that of the unmodified carbons. Despite this, the order of $Q_{\mathrm{F}(\mathrm{ZrO} 2 \times \mathrm{H} 2 \mathrm{O})}$ derived for the three adsorbents can be predicted under this assumption. Until now, however, this treatment has not been applied to the data obtained in this work because the $Q_{F(C)}$ needed for the calculation should be precisely determined prior to the calculation, and, until now, highly accurate $Q_{\mathrm{F}(\mathrm{C})}$ have not been obtained (Figure 4). This remains an issue for further investigation. 


\subsection{Effect of $\mathrm{pH}$ on $\mathrm{F}^{-}$Adsorption}

$\mathrm{pH}$ affects the $\mathrm{F}^{-}$adsorption onto $\mathrm{Zr}$-impregnated adsorbents [10,12]. Here, the dependence of $\mathrm{F}^{-}$adsorption capacity on $\mathrm{pH}$ was examined. Figure 5 shows the dependence of $\mathrm{F}^{-}$uptake observed for the prepared adsorbents. The $Q_{\mathrm{F}}$ represents the equilibrium uptakes measured using $50 \mathrm{mg} / \mathrm{L} \mathrm{F}^{-}$ solutions. As confirmed, in all cases, the $\mathrm{F}^{-}$uptake markedly decreased as the $\mathrm{pH}$ increased.

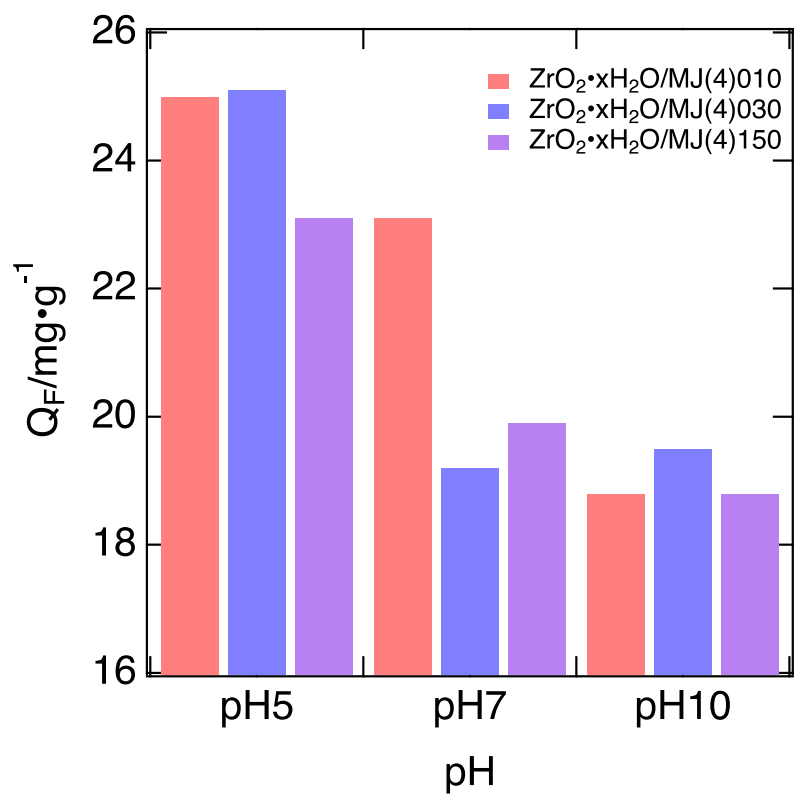

Figure 5. $\mathrm{F}^{-}$uptake measured under different $\mathrm{pH}(5,7$, and 10$)$.

A preliminary calculation of $p$-values was attempted to check whether the observed difference in the $\mathrm{F}^{-}$uptake was statistically significant. Here, the measured $\mathrm{F}^{-}$uptakes were grouped into $\mathrm{pH} 5,7$, and 10. Each group contained the $Q_{\mathrm{F}}$ measured for $\mathrm{ZrO}_{2} \cdot \mathrm{xH}_{2} \mathrm{O} / \mathrm{MJ}(4) 010,030$, and 150. This treatment was not completely appropriate, because the $Q_{\mathrm{F}}$ observed for the three adsorbents should differ, but based on this treatment, the overall trend of the $\mathrm{pH}$ dependence could be evaluated. For $\mathrm{pH} 5$ and 10, the $p$-value was calculated to be 0.0015 , indicating that the difference in the $Q_{\mathrm{F}}$ under the two $\mathrm{pH}$ conditions was sufficiently significant for a significance level of $5 \%$. Conversely, for $\mathrm{pH} 5$ and 7 , the $p$-value was 0.055 , and for $\mathrm{pH} 7$ and 10 , it was 0.24 . These results indicate that the $\mathrm{pH}$-dependent differences in $Q_{\mathrm{F}}$ can be found by comparing $Q_{\mathrm{F}}$ in the wide $\mathrm{pH}$ range.

This tendency agrees with that observed in the results reported previously. Therefore, the $\mathrm{F}^{-}$adsorption in the present cases occurs through the mechanism proposed by a previous study. Dou et al. [12] proposed the mechanism of $\mathrm{F}^{-}$adsorption by $\mathrm{ZrO}_{2} \cdot \mathrm{xH}_{2} \mathrm{O}$ involving protonation and deprotonation of hydroxyl groups bound to surface $\mathrm{Zr}$. If a hydroxyl group is protonated to give $-\mathrm{OH}_{2}{ }^{+}$under acidic conditions, $\mathrm{F}^{-}$can smoothly attack $\mathrm{Zr}$ to create the $\mathrm{Zr}-\mathrm{F}$ bond; then, the protonated hydroxyl group is released as water. Conversely, under basic conditions, $\mathrm{OH}^{-}$abstracts $\mathrm{H}^{+}$from the hydroxyl groups to form water, and surface species containing $\mathrm{Zr}-\mathrm{O}^{-}$are left as residue. These species possess negative charge, and hence it is difficult for $\mathrm{F}^{-}$to approach $\mathrm{Zr}$. The present results support the proposed mechanism.

If the electric charge of adsorption sites containing both $\mathrm{Zr}-\mathrm{F}$ and $\mathrm{Zr}-\mathrm{OH}$ after $\mathrm{F}^{-}$adsorption can be controlled by treatment with $\mathrm{OH}^{-}$, it will be possible to retrieve $\mathrm{F}^{-}$from the adsorbent through simple washing of the adsorbent using alkali solution. If $\mathrm{F}^{-}$can be retrieved with high yield, this method is industrially valuable because fluorine is a vital element as a component of glass, medicines, and polymer materials, among others. 


\section{Conclusions}

In this study, $\mathrm{F}^{-}$adsorption characteristics exhibited by the $\mathrm{ZrO}_{2} \cdot \mathrm{xH}_{2} \mathrm{O}$ /templated mesoporous carbon adsorbents were examined, and influence of the pore structure of the mesoporous carbons on the $\mathrm{F}^{-}$adsorption was discussed. The mesoporous carbons were successfully modified with $\mathrm{ZrO}_{2} \cdot \mathrm{xH}_{2} \mathrm{O}$ generated through the auto-hydrolysis of $\mathrm{ZrClO}_{2}$ in aqueous solution. The $\mathrm{F}^{-}$adsorption capacity was found to depend on the mesopore size of the unmodified mesoporous carbons. The effect of the size is based on the difference in the immobilized amount and the particle structure (particle size and surface area) of $\mathrm{ZrO}_{2} \cdot \mathrm{xH}_{2} \mathrm{O}$. Currently, direct observation of the immobilized $\mathrm{ZrO}_{2} \cdot \mathrm{xH}_{2} \mathrm{O}$ has not been achieved. Subsequently, high-resolution transmission electron microscopy (TEM) may provide clear evidence of the difference in particle structure. This will be a subject for further study.

Moreover, the effect of $\mathrm{pH}$ on the $\mathrm{F}^{-}$adsorption was examined. A shift of $\mathrm{pH}$ toward basic condition was found to decrease the $\mathrm{F}^{-}$uptake. This can be explained based on the reaction mechanism involving protonation/deprotonation of $\mathrm{Zr}-\mathrm{OH}$ moieties. Utilizing this dependence, it will be possible to retrieve $\mathrm{F}^{-}$from the used adsorbent and regenerate the adsorbent. These are expected to be realized in future works.

Funding: This research received no external funding.

Acknowledgments: The XPS experiments were carried out using an X-ray photoelectron spectrometer (JEOL JPS-9200) installed at the Laboratory of XPS analysis, Hokkaido University (Technician: Mr. Keita Suzuki), supported by the Nanotechnology Platform Program of the Ministry of Education, Culture, Sports, Science and Technology (MEXT), Japan. The $\mathrm{N}_{2}$ adsorption isotherms were recorded using a gas sorption analyzer (Quantachrome Autosorb) installed at the Institute of Catalysis, Hokkaido University (Technician: Mr. Shuhei Shimoda), the analyzer is registered in the Open Facility system managed by the Global Facility Center, Creative Research Institution, Hokkaido University. The author thanks Editage (www.editage.jp) for English language editing.

Conflicts of Interest: The authors declare no conflict of interest.

\section{References}

1. Mohapatra, M.; Anand, S.; Mishra, B.K.; Giles, D.E.; Singh, S. Review of fluoride removal from water. J. Environ. Manag. 2009, 91, 67-77. [CrossRef]

2. Vences-Alvarez, E.; Velazquez-Jimenez, L.H.; Chazaro-Ruiz, L.F.; Diaz-Flores, P.E.; Rangel-Mendez, J.R. Fluoride removal in water by a hybrid adsorbent lanthanum-carbon. J. Colloid Interfaces Sci. 2015, 455, 194-202. [CrossRef]

3. Chen, L.; He, S.; Wang, T.-J.; Su, C.-L.; Zhang, C.; Jin, Y. Synthesis of Iron-Doped Titanium oxide Nanoadsorbent and Its Adsorption Characteristics for Fluoride in Drinking Water. Ind. Eng. Chem. Res. 2012, 51, 13150-13156. [CrossRef]

4. Chen, L.; He, B.-Y.; He, S.; Wang, T.-J.; Su, C.-L.; Jin, Y. Fe-Ti oxide nano-adsorbent synthesized by co-precipitation for fluoride removal from drinking water and its adsorption mechanism. Powder Technol. 2012, 227, 3-8. [CrossRef]

5. Cai, H.-M.; Chen, G.-J.; Peng, C.-Y.; Zhang, Z.-Z.; Dong, Y.-Y.; Shang, G.-Z.; Zhu, X.-H.; Gao, H.-J; Wan, X.-C. Removal of fluoride from drinking water using tea waste loaded with $\mathrm{Al} / \mathrm{Fe}$ oxides: A novel, safe, and efficient biosorbent. Appl. Surf. Sci. 2015, 328, 34-44. [CrossRef]

6. Zhao, Y.; Li, X.; Liu, L.; Chen, F. Fluoride removal by Fe(III)-loaded ligand exchange cotton cellulose adsorbent from drinking water. Carbohydr. Polym. 2008, 72, 144-150. [CrossRef]

7. Sun, Y.; Fang, Q.; Dong, J.; Cheng, X.; Xu, J. Removal of fluoride from drinking water by natural stilbite zeolite modified with Fe(III). Desalination 2011, 277, 121-127. [CrossRef]

8. Terasaka, S.; Kamitakahara, M.; Yokoi, T.; Matsubara, H. Effect of carbonate inclusion on fluoride ion removal by hydroxyapatite: A discussion from the viewpoint of hydroxyapatite dissolution. J. Ceram. Soc. Jpn. 2016, 124, 1211-1216. [CrossRef]

9. Janardhana, C.; Rao, G.N.; Sathish, R.S.; Kumar, P.S.; Kumar, V.A.; Madhav, M.V. Study on defluoridation of drinking water using zirconium ion impregnated activated charcoals. Indian J. Chem. Technol. 2007, 14, 350-354. 
10. Sathish, R.S.; Sairam, S.; Raja, V.G.; Rao, G.N.; Janardhana, C. Defluoridation of Water Using Zirconium Impregnated Coconut Fiber Carbon. Sep. Sci. Technol. 2008, 43, 3676-3694. [CrossRef]

11. Alagumuthu, G.; Rajan, M. Equilibrium and kinetics of adsorption of fluoride onto zirconium impregnated cashew nutshell carbon. Chem. Eng. J. 2010, 158, 451-457. [CrossRef]

12. Dou, X.; Mohan, D.; Pittman, C.U., Jr.; Yang, S. Remediating fluoride from water using hydrous zirconium oxide. Chem. Eng. J. 2012, 198, 236-245. [CrossRef]

13. Barathi, M.; Kumar, A.S.K.; Rajesh, N. A novel ultrasonication method in the preparation of zirconium impregnated cellulose for effective fluoride adsorption. Ultrason. Sonochem. 2014, 21, 1090-1099. [CrossRef] [PubMed]

14. Velazquez-Jimenez, L.H.; Hurt, R.H.; Matos, J.; Rangel-Mendez, J.R. Zirconium-Carbon Hybrid Sorbent for Removal of Fluoride from Water: Oxalic Acid Mediated $\mathrm{Zr}(\mathrm{IV})$ Assembly and Adsorption Mechanism. Environ. Sci. Technol. 2014, 48, 1166-1174. [CrossRef]

15. Matsui, K.; Ohgai, M. Effects of $\mathrm{ZrOCl}_{2}$ Concentration and Reaction Temperature on the Formation Process of Hydrous-Zirconia Fine Particles. J. Ceram. Soc. Jpn. 1999, 107, 949-954. [CrossRef]

16. Morishita, T.; Suzuki, R.; Tsumura, T.; Habazaki, H.; Inagaki, M. Preparation of mesoporous carbons by carbonization of the mixtures of poly(vinyl alcohol) with magnesium salts. TANSO 2006, 223, 220-226. [CrossRef]

17. Morishita, T.; Ishihara, K.; Kato, M.; Tsumura, T.; Inagaki, M. Mesoporous carbons prepared from mixtures of magnesium citrate with poly(vinyl alcohol). TANSO 2007, 226, 19-24. [CrossRef]

18. Konno, H.; Onishi, H.; Yoshizawa, N.; Azumi, K. MgO-templated nitrogen-containing carbons derived from different organic compounds for capacitor electrodes. J. Power Source 2010, 195, 667-673. [CrossRef]

19. Brunauer, S.; Emmett, P.H.; Teller, E. Adsorption of Gases in Multimolecular Layers. J. Am. Chem. Soc. 1938, 60, 309-319. [CrossRef]

20. Cisar, A.; Corbett, J.D.; Daake, R.L. The Zirconium Dichloride Phase Region. Synthesis, Structure, and Photoelectron Spectral Studies of $3 \mathrm{R}-\mathrm{ZrCl}_{2}, 6 \mathrm{~T}-\mathrm{Zr}_{1.05} \mathrm{Cl}_{2}$, and Related Phases. Inorg. Chem. 1979, 18, 836-843. [CrossRef]

21. Baba, Y.; Sasaki, T.A. Application of X-ray-induced Auger electron spectroscopy to state analysis of hydrogen implanted in $\mathrm{Y}, \mathrm{Zr}$, and $\mathrm{Nb}$ metals. Surf. Interf. Anal. 1984, 6, 171-173. [CrossRef]

22. Kanô, F.; Abe, I.; Kamaya, H.; Ueda, I. Fractal model for adsorption on activated carbon surfaces: Langmuir and Freundlich adsorption. Surf. Sci. 2000, 467, 131-138. [CrossRef] 